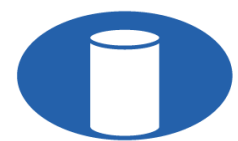

IBRACON Structures and Materials Journal

Revista IBRACON de Estruturas e Materiais

ORIGINAL ARTICLE

\title{
Evaluation of rheological models for concrete submitted to alkali-aggregate reaction based on numerical analysis of damping - free expansion
}

\section{Avaliação de modelos reológicos para concreto submetido a reação álcali- agregado baseada em análise numérica de amortecimento - expansão livre}

\author{
Marlon de Barros Cavalcanti ${ }^{\mathrm{a}}$ \\ Sandro Marden Torres ${ }^{\mathrm{b}}$ \\ Marçal Rosas Florentino Lima Filho ${ }^{\mathrm{c}}$ \\ Alexsandro José Virgínio dos Santos ${ }^{\mathrm{d}}$ (D)
}

\begin{abstract}
${ }^{a}$ Companhia Hidro Elétrica do São Francisco - CHESF, Departamento de Engenharia de Geração Eólica, Recife, PE, Brasil

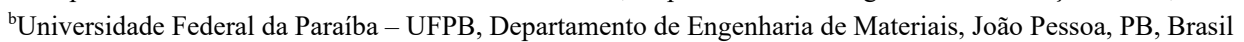

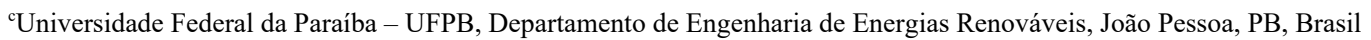

${ }^{\mathrm{d} U n i v e r s i d a d e ~ F e d e r a l ~ d a ~ P a r a i ́ b a ~-~ U F P B, ~ D e p a r t a m e n t o ~ d e ~ E n g e n h a r i a ~ E l e ́ t r i c a, ~ J o a ̃ o ~ P e s s o a, ~ P B, ~ B r a s i l ~}$
\end{abstract}

Received 04 October 2019

Accepted 06 July 2020

\begin{abstract}
The Alkali-Aggregate Reaction (AAR) phenomenon in concrete structures is perceived via expansion and cracking, swelling of gel like material, causing damage and disruption in structural elements. Despite extensive standardization, AAR cases are still persistently occurring worldwide. The literature on susceptibility of concrete to AAR reported examples of false negative and positive results. Hence, long-term prediction is a problem still posing great challenge to engineers. The severity of AAR on the structural integrity can be mostly elucidated by the assessment of the historic of elastic properties. There is consensus that AAR causes decrease in the load capacity concrete, reflected by reduction of elasticity modulus due damage progresses. Non-destructive techniques are often used as first approach, as they can provide relatively fast assessment in situ as well as in large structural elements. Its data interpretation carries certain degree of complexity due intrinsic characteristic of many of these methods. This is the case of Ultrasonic Pulse Velocity (UPV), which have been considered to present several limitations for such purpose. This paper deals the potential use of the Longitudinal Resonance Frequency (LRF) method as tool to evaluate the elastic historic of AAR prone elements. The LRF possesses higher energy than UPV. Also, using modulation of frequency in input signal combined the test geometry, the LRF allow application to larger samples as well as to extract complementary information alongside the dynamic elastic modulus. This way, the LRF was applied to study concrete beams tested under controlled conditions for about 1.5 year. The independent variables to the tests are: time, frequency, aggregate type, cement content, alkali content and water to cement ratio. The dependent variables are: damping, loss factor and elasticity modulus. The analysis associate damage with vibration damping, confirming reduction of elasticity through damage with experimental validation and prediction of AAR under rheological model.
\end{abstract}

Keywords: alkali-aggregate reaction, rheological model, damping.

Resumo: O fenômeno da Reação Álcali-Agregado (RAA) em estruturas de concreto é percebido via expansão e fissuração, inchando o gel como material, causando danos e rupturas nos elementos estruturais. Apesar da extensa padronização, casos de RAA ainda ocorrem persistentemente em todo o mundo. A literatura sobre suscetibilidade de concreto a RAA relatou exemplos de resultados falso negativo e positivo. Portanto, previsão a longo prazo é um problema que ainda representa um grande desafio para os engenheiros. A severidade da RAA sobre a integridade estrutural pode ser principalmente elucidada pela avaliação do histórico das propriedades elásticas. Existe consenso de que RAA causa diminuição da capacidade de carga do concreto, refletida pela redução do módulo de elasticidade devido ao progresso dos danos. Técnicas não destrutivas são

Corresponding author: Marlon de Barros Cavalcanti. E-mail: marlonbc@chesf.gov.br, marlonbcavalcanti@gmail.com

Financial support: Companhia Hidro Elétrica do São Francisco (Chesf).

Conflict of interest: Nothing to declare.

This is an Open Access article distributed under the terms of the Creative Commons Attribution License, which permits unrestricted use, distribution, and reproduction in any medium, provided the original work is properly cited. 
frequentemente usadas como primeira abordagem, pois podem fornecer uma avaliação relativamente rápida in situ, bem como em grandes elementos estruturais. A interpretação dos dados carrega certo grau de complexidade devido às características intrínsecas de muitos desses métodos. Este é o caso de Velocidade de Pulso Ultrassônico (VPU), que foi considerado como apresentando várias limitações para esse propósito. Este artigo trata o potencial uso do método de Frequência de Ressonância Longitudinal (FRL) como ferramenta para avaliar o histórico elástico de elementos propensos a RAA. A FRL possui maior energia que VPU. Além disso, usando modulação de frequência no sinal de entrada combinada à geometria de teste, a FRL permite aplicação em amostras maiores, bem como extrair informações complementares ao lado do módulo elástico dinâmico. Dessa forma, a FRL foi aplicada para estudar vigas de concreto testadas sob condições controladas por cerca de 1,5 ano. As variáveis independentes para os testes são: tempo, frequência, tipo de agregado, teor de cimento, teor de álcalis e relação água/cimento. As variáveis dependentes são: amortecimento, fator de perda e módulo de elasticidade. A análise associa dano com amortecimento da vibração, confirmando a redução de elasticidade através do dano com validação experimental e predição de RAA sob modelo reológico.

Palavras-chave: reação álcali-agregado, modelo reológico, amortecimento.

How to cite: M. B. Cavalcanti, S. M. Torres, M. R. F. Lima Filho, and A. J. V. Santos, "Evaluation of rheological models for concrete submitted to alkali-aggregate reaction based on numerical analysis of damping - free expansion", Rev. IBRACON Estrut. Mater., vol. 14, no. 2, e14205, 2021, https://doi.org/10.1590/S1983-41952021000200005

\section{INTRODUCTION: CRITICAL LITERATURE REVIEW}

Alkali-Aggregate Reaction (AAR) is an expansion deleterious phenomenon that affects concrete's long-term performance and durability. Its origin is a chemical reaction between silicon and alkaline ions present in concrete pore solution, producing highly hydrophilic gel that expands over time in presence of water, introducing stresses in the concrete structure.

The pressure induced over time by the gel produced of the AAR can cause macroscopic expansion and internal damage to the material's microstructure. The reaction does not always lead to expansion, if there is enough empty space to be filled by the gel, such as pores and cracking, the volume of the concrete remains unchanged.

The concrete affected by AAR is subject to expansion and consequently to degradation, which can affect the concrete structures operationality, not necessarily the total ruin. For example, in dams, there are records of operational problems, due to the closure of expansion joints and alteration of the original geometry of structural components.

In recent years there has been an increase in the search for reliable techniques for dynamic non-destructive testing in the detection of damage to structures and materials (Butterworth et al. [1]; Leśnicki et al. [2]; Barreto [3]; Gutenbrunner et al. [4]; among others). This is due to the fact that the damage causes changes in parameters such as damping, consequently, in stiffness, where the study of damping and its evolution over time can direct the effective methodology for detecting stiffness degradation in concretes submitted to AAR.

\subsection{Damping in structural materials}

Among the possible methods for determining the elasticity modulus by dynamic testing of materials can to mention: ultrasonic pulse velocity (or ultrasonic longitudinal wave vibration frequency, i.e., above $20 \mathrm{kHz}-\mathrm{ABNT}$ NBR 8802 [5]) and resonance frequency (longitudinal, transversal, flexional and torsional).

Dynamic tests by resonance frequency carry two characteristics that can have great potential in the analysis of damage to structures, which are: a) Frequency response capable of representing the state of tension; and b) Ability to measure damping, given the fact that the energy level in the method is high enough for detection and, even so, the induced stress is below which damage can be produced.

It's worth noting that, according to Butterworth et al. [1], damping is the most difficult to predict dynamic property, as it cannot be deduced of physical properties of the structure, unlike mass and rigidity, need of experimental investigation.

\subsection{Damping in concrete}

Work conducted by Nagy [6], for damping in concrete, consisted of equipment for sample excitation and receivers for Fast Fourier Transform (FFT) analysis, where the resonance frequency corresponds to the "peak" showed of the curve in Figure 1, which also show the calculation of the loss factor $(\eta)$ by the half-power bandwidth method. Equation 1 reproduces and complements the formulation expressed in Figure 1, inserting the damping ratio parameter $(\xi)$. 


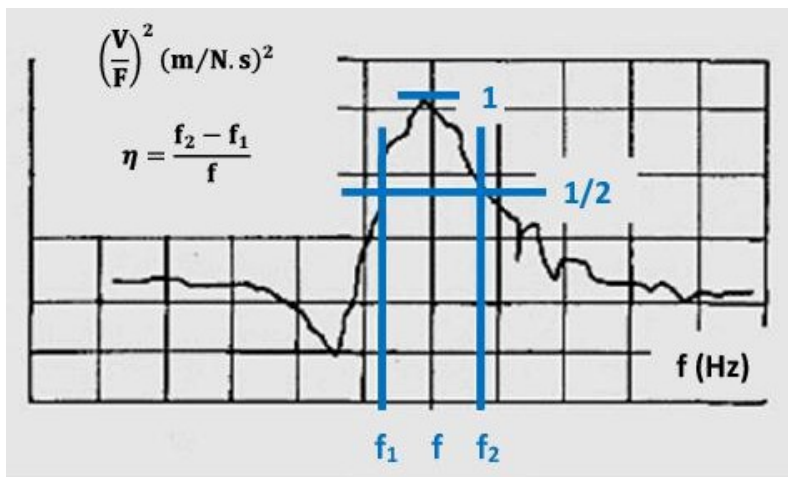

Figure 1. Schematic diagram for calculating the loss factor (adapted of Nagy [6]).

$\frac{\Delta \omega}{\omega_{\text {res }}}=\frac{f_{2}-f_{1}}{f}=2 \xi \simeq \eta$

\subsection{Damping and AAR}

Work conducted by Leśnicki et al. [2] states that the difficulties in quantifying damage to concrete originate of its complex microstructure. Other complications arise of possible chemical reactions, such as AAR, which can considerably and continuously modify the existing microstructure.

The gel formed not only provides another phase in the already complex microstructure, but it is also hygroscopic. The swelling of the gel induces internal stress within of the concrete matrix, which, if enough, can cause interfacial detachment, cracking initiation and propagation.

The cracking resulting of the expansion imposed by the AAR, distributed in the structural member, reduce the mechanical stiffness and, consequently, the resonance frequencies of the member. These cracking can be considered part of an imperfect interconnected system, which also includes interfaces between the aggregate and the surrounding mortar or cement paste, as well as other defects.

A typical set of Frequency Response Function (FRF) graphs for undamaged concrete sample (S3) and concrete sample highly reactive to AAR (S1) are shown in Figure 2, where the differences in the resonance curves obtained are clear [2].
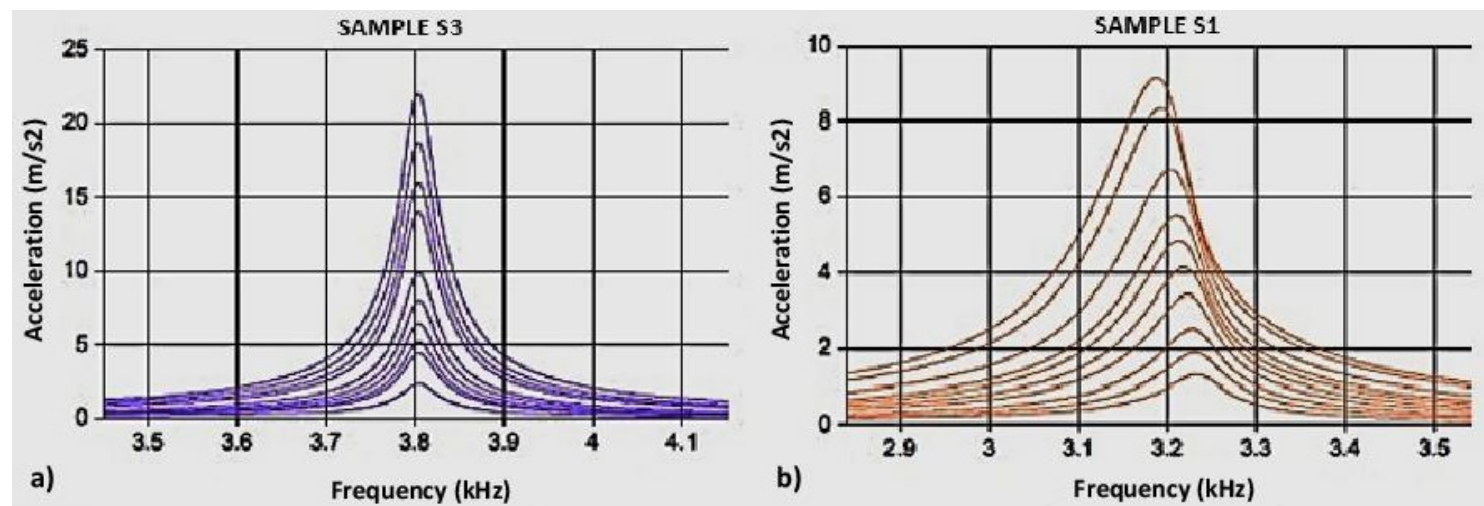

Figure 2. a) FRF to sample S3; b) FRF to sample S1 (adapted of Leśnicki et al. [2]).

The results, according Leśnicki et al. [2], show potential for the detection of AAR in concrete through resonance tests in conjunction with expansion tests, where resonance show the frequency decay in the undamaged sample (S3) of $3.8 \mathrm{kHz}$ to approximately $3.2 \mathrm{kHz}$ in the highly reactive sample (S1). It's also noticed a decrease in the amplitude of accelerations of one sample to the other, about $23 \mathrm{~m} / \mathrm{s}^{2}$ to approximately $9 \mathrm{~m} / \mathrm{s}^{2}$. This behavior of decreasing of the frequency and amplitude is typical of viscous damping, as showed in Figure 3, considering literature to vibration damping of classical mechanics [7]. 


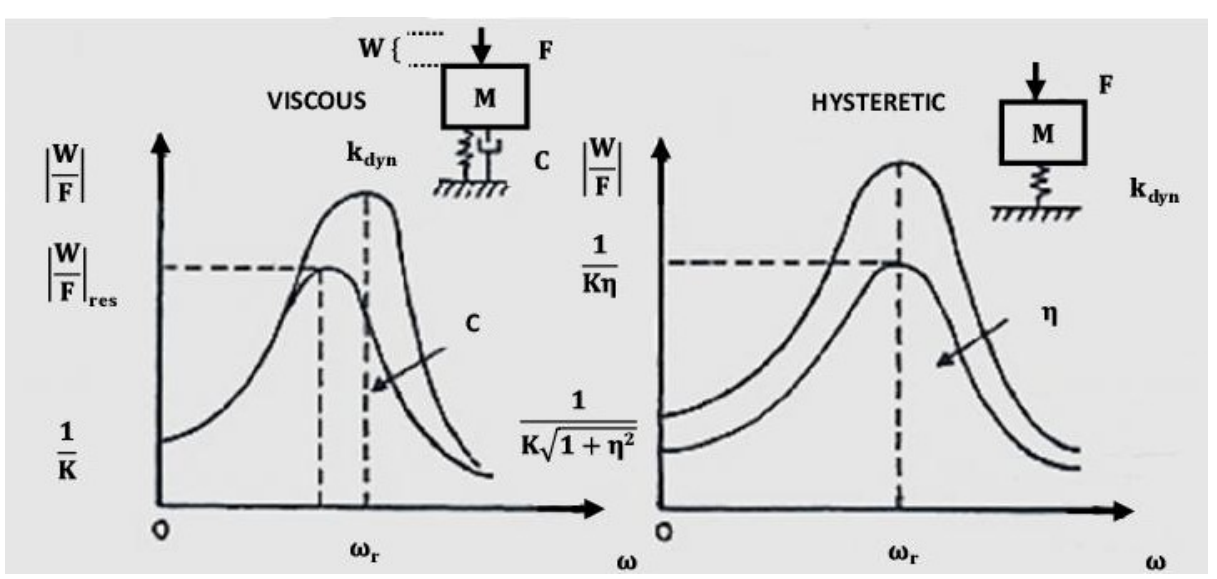

Figure 3. Dynamic response of viscous and hysteresis systems (adapted of Nashif et al. [7]).

\subsection{Non-destructive testing}

Within of approach proposed in the present study, based on damping, the parameters to be obtained of the resonance tests are: damping, loss factor and elasticity modulus.

\subsubsection{Ultrasonic pulse velocity}

Figure 4 show the results of Ultrasonic Pulse Velocity (UPV) tests carried out on the same concrete beams tested in the resonance in this study.

It's noticed an increase in UPV over the time of the tests, in which the dynamic elastic modulus is proportional the pulse propagation velocity, it can be deduced that the concrete beams, including those affected by AAR (R \# - beam affected by AAR), are gaining rigidity, when in fact, the beams with reactive material are undergoing degradation, as verified in the resonance tests and where Barreto [3] confirmed that the ultrasound is not sensitive to the detection of AAR.

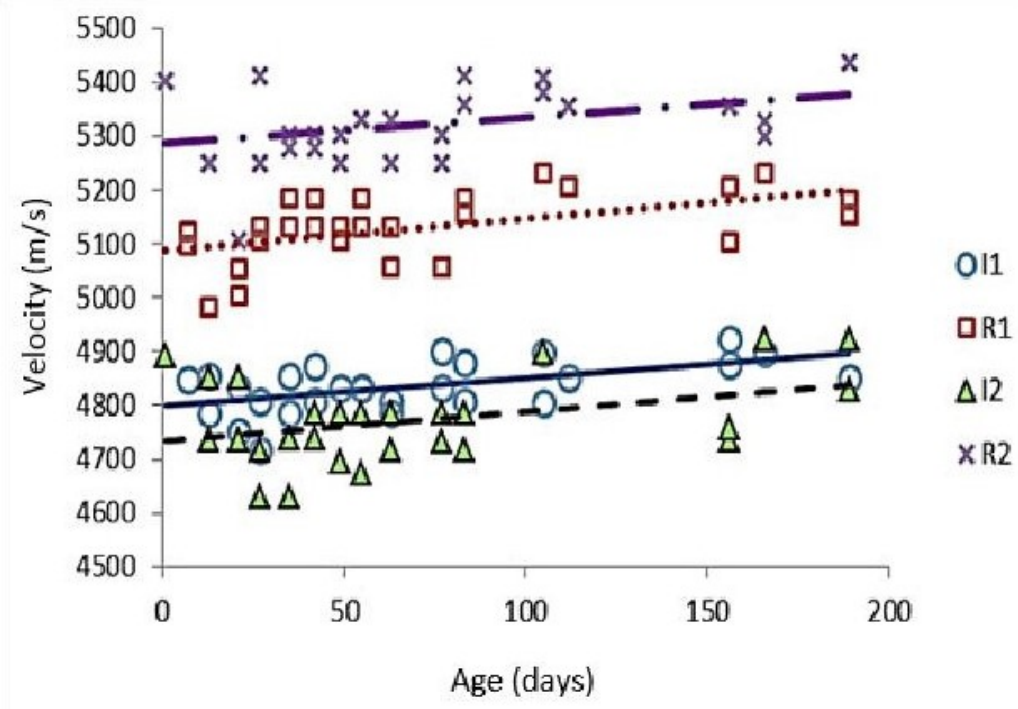

Figure 4. UPV vs. age in the concrete beams tested (see Table 1) [3].

The possible explanation for this lower sensitivity of the ultrasound, in face of the AAR phenomenon, may be correlated to the lower dissipative energy condition of the ultrasound in relation to non-Newtonian fluid, such as the 
AAR gel. In addition, interference signals of the concrete microstructure and signals originating of damage coexist during the ultrasound test, as shown in Figure 5.

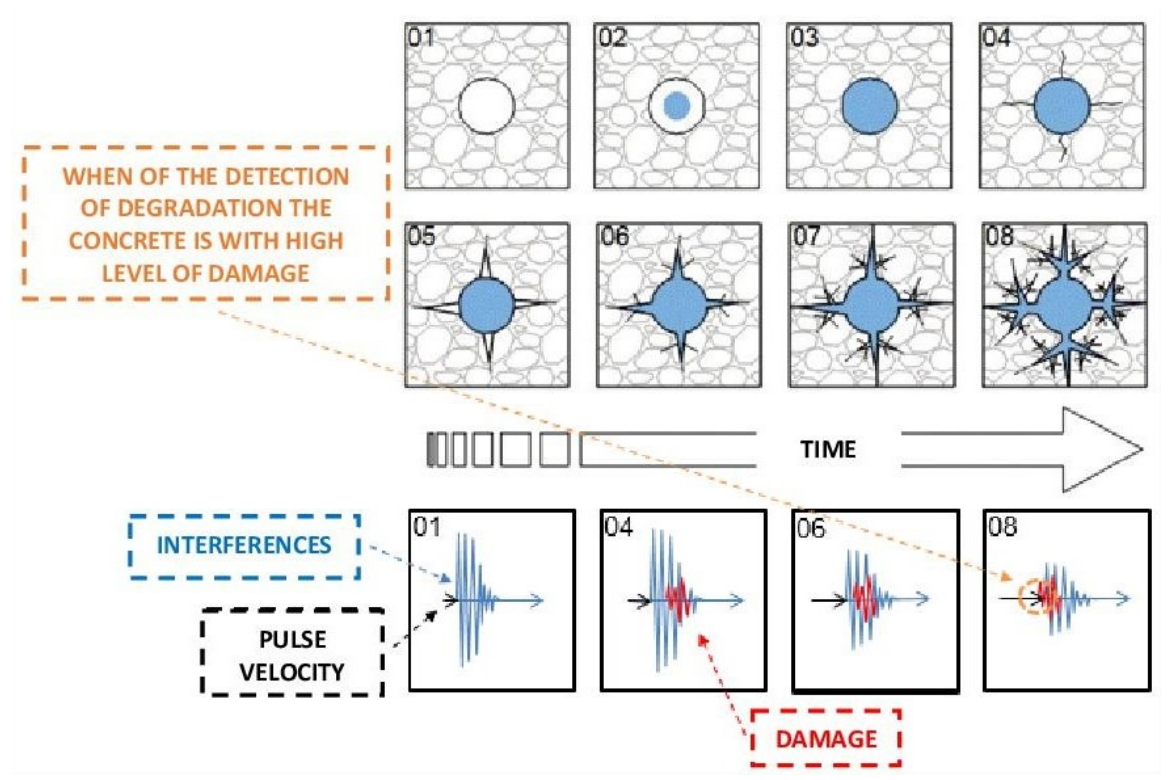

Figure 5. Illustration of UPV test vs. damage by the growth of gel of AAR (AUTHOR/UFPB).

Figure 5 sequences the growth of AAR gel in concrete void until the gel to fill the void, when the gel then starts to tension the concrete, where gel and concrete gain apparent rigidity, and cracking appear later, where the gel starts to fill the gaps, tensioning the concrete, in progressive damage cycle up to the point where the detection of degradation by ultrasound is evident.

\subsubsection{Resonance frequency testing}

In the case in question, for Longitudinal Resonance Frequency (LRF) tests conducted by Barreto [3], longitudinal force of sinusoidal behavior with variable frequency was applied in a time interval of 8 seconds, by the logarithmic scanning system of the equipment used (AGILENT 33220A [8]), where the manufacturer (AGILENT TECHNOLOGIES) reports that logarithmic scanning is useful to cover a wide range of frequencies, which in low resolution could be lost with the linear scanning system.

\subsection{LRF in structural specimens (experimental apparatus)}

\subsubsection{Applied LRF to steel bar (experiment calibration)}

In obtaining of the parameters of interest, considering test procedure adopted, the ASTM E 756 [9] assert that if the elasticity modulus obtained for steel (SAE 1020) is not approximately $207 \mathrm{GPa}$ (data of the literature also suggest 205 to $210 \mathrm{GPa}$ ) and the loss factor is not approximately 0.002 to 0.001 for the $1 \mathrm{st}$ and 2 nd modes and 0.001 or less for the higher modes, as in the numerical approach of this study, then there must be a problem with the device configuration or other in the measurement system.

In the test configuration of this study the result of the loss factor and elasticity modulus, measured dynamically, through LRF, for the steel adopted, respectively, corresponds to 0.00041 and $212.8 \mathrm{GPa}$, considering the 3rd experimental mode ("peak" at 3,948.4 Hz) (see Figure 6), being the 1st natural mode with "peak" at 3,436 Hz according to the described geometry of the steel bar (steel cylinder measuring $1.317 \mathrm{~m}$ in length with circular cross section of diameter $0.0508 \mathrm{~m}$ ) and supposed $210 \mathrm{GPa}$ module, where the divergence related to the 1 st and $3 \mathrm{rd}$ experimental mode is due to the appearance of two previous "peaks" in the experimental result, arising of accessory modes and imperfections in the configuration. 


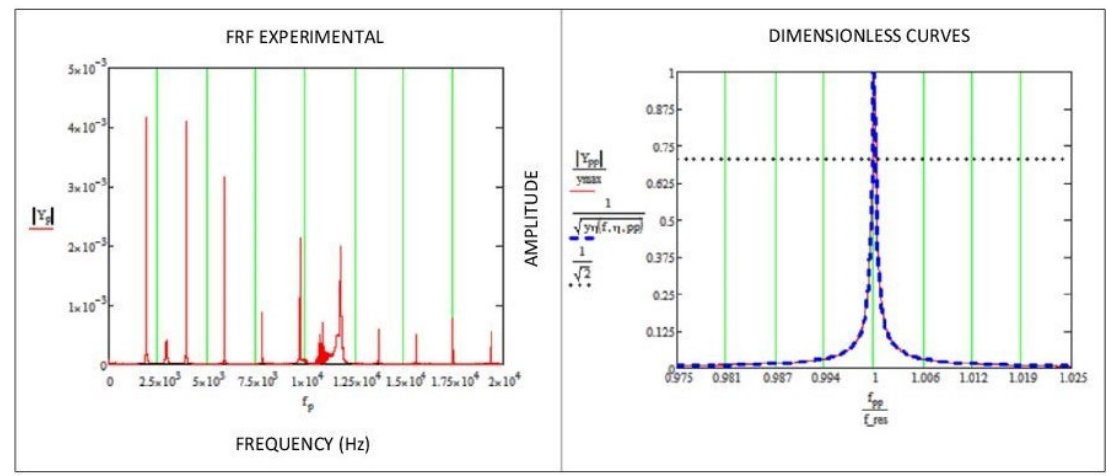

Figure 6. FRF longitudinal experimental and dimensionless resonance curve for the steel in 3rd mode; experimental - continuous line; theoretical - dashed line (AUTHOR).

However, the results of the test configuration of this study agree with the prescription of values mentioned by ASTM E 756 [9] for steel, considering the technique employed, showing the feasibility of the test procedure to be used in the analysis of concrete submitted to AAR.

\subsubsection{Applied LRF to AAR concrete specimens}

In concrete, inside of the test procedure applied LRF to steel bar, the longitudinal force was applied at the end of the longitudinal axis of concrete beam with approximately $28.4 \mathrm{~kg}$ as shown in Figure 7.

The dynamic test was performed using shaker of low intensity and accelerometer. The oscillation was performed applying a sweep of $100 \mathrm{~Hz}$ up to $20 \mathrm{kHz}$. The time domain data was recorded and further treated with FFT.

The signals collected to LRF test in a set of 10 measurements with a window of 10 seconds each, that corresponds one reading, had analyzed the last window with better signal stabilization.

In this case, one has sampling frequency of 1,000,000 data, which corresponds one data collected at each time interval of 10 microseconds, where results of the analysis carried out, likewise that to the steel bar, are shown to the concrete beams tested.

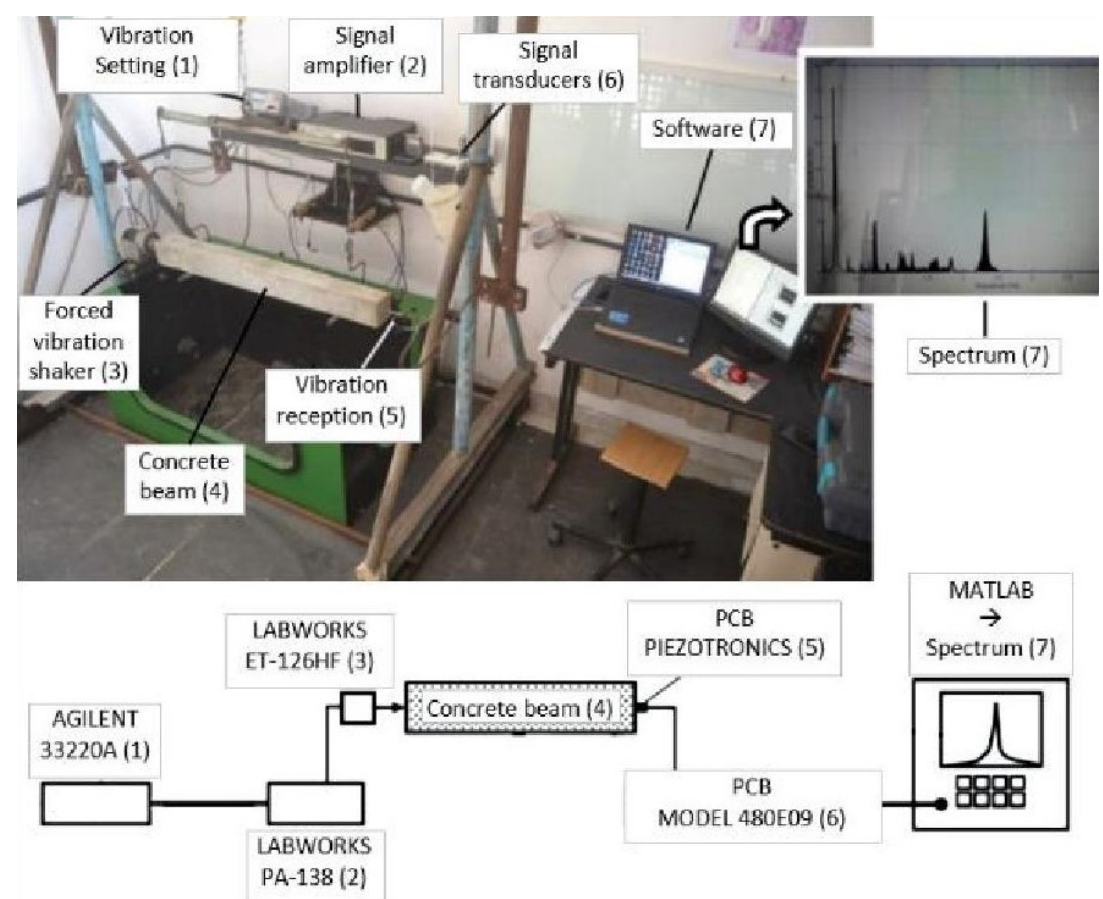

Figure 7. Scheme of the LRF test (modified of Barreto [3]). 


\section{METHODOLOGY}

This paper is dived in two parts. The first part addresses the fundamental knowledge on main energy dissipation mechanisms. In this part, the mathematical formulations of damping in concrete structures is discussed for the most appropriate rheology and its mathematical formulation is developed with respect the finite elements method (FEM) to LRF.

In the second part, the worked approach is applied to an experimental set of data produced by Barreto [3], what consisted of acquiring data of LRF test performed to concrete beams measuring $1.14 \mathrm{~m}$ in length with square cross section $(0.1 \times 0.1 \mathrm{~m})$.

The concrete beams were cast with two levels of cement content $\left(420\right.$ and $\left.500 \mathrm{~kg} / \mathrm{m}^{3}\right)$ and two types of aggregates (reactive and innocuous) (see Table 1). Was added $\mathrm{NaOH}$ to the casting water (1.0 M NaOH + Deionized), which water to cement ratio (w/c) was made constant for all specimens in 0.45 (see Table 2). The samples were stored in wet room at $38^{\circ} \mathrm{C}$ for about 1.5 year.

\section{RESULTS AND DISCUSSIONS}

\subsection{Part 1: mathematical formulations of damping in concrete}

\subsubsection{Damping equivalence}

Considering the observations made to concrete by Leśnicki et al. [2], associating mechanics of vibration damping described by Nashif et al. [7], still having the changes in amplitude and resonance frequency, the equivalence between viscous and hysteresis damping was adopted, as can be seen by comparing the behaviors showed in Figures 2 and 3, to obtain the damping in the analysis of the resonance frequency in this study, being one of the biggest advantages in assuming hysteresis damping the possibility of using the correspondence principle in complex analysis, where complex number can be replaced by real value in damping accounting [7] (see Figure 8).

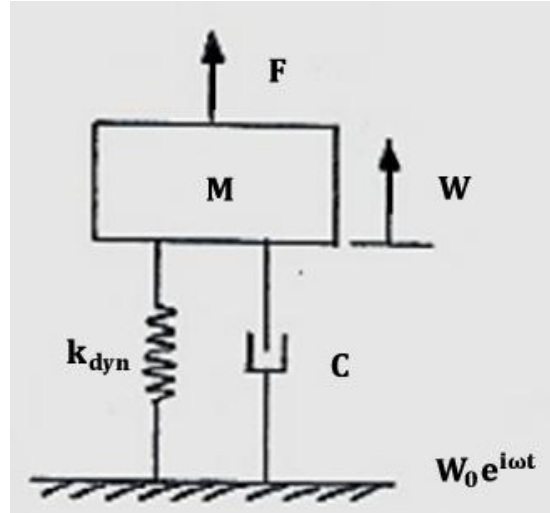

a) viscous damping

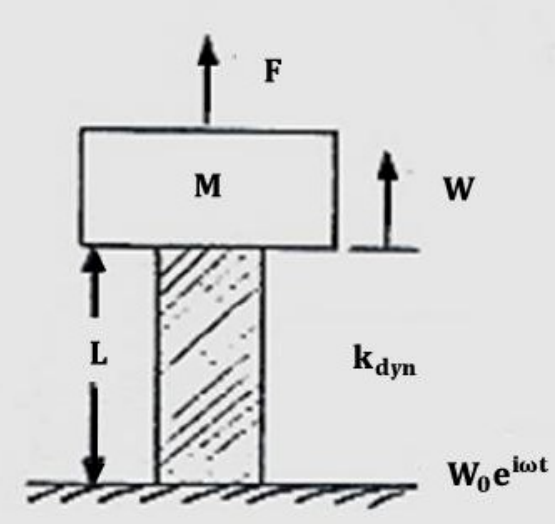

b) hysteretic damping

Figure 8. Damping for single degree of freedom: a) Viscous; b) Hysteresis (adapted of Nashif et al. [7]).

Another important point in the analyzes is the difference between the viscous and hysteretic damping system, where in the viscous system the energy dissipated per cycle depends linearly on the oscillation frequency, while in the hysteretic system the energy dissipated is independent of the frequency.

\subsubsection{Damping calculation}

In order to avoid the drawbacks of the half-power bandwidth method, can make use of least squares for curve fitting method when adjusting the theoretical curve to the experimental resonance curve. 
For this, consider the parameters of the resonance test when calculating the viscous damping ratio, for single degree of freedom system, as shown in Figure 8, based on the equation of the damped motion governed by Newton's second law and equations for vibration damping by Nashif et al. [7], the equation can be expressed as:

$$
w(t)=w e^{i \omega t}
$$

$\mathrm{Kw}(\mathrm{t})+\mathrm{Cw}^{\prime}(\mathrm{t})+\mathrm{Mw}^{\prime \prime}(\mathrm{t})=\mathrm{F}(\mathrm{t})=\overline{\mathrm{F}} \mathrm{e}^{\mathrm{i} \omega \mathrm{t}} \therefore \mathrm{i}=\sqrt{-1}$

To dimensionless excitation frequency, one has:

$$
\Omega=\frac{\omega}{\omega_{\text {res }}}=\frac{\omega}{\sqrt{\frac{K}{M}}} \therefore \omega_{\text {res }}=\sqrt{\frac{K}{M}}
$$

The damping ratio being defined as:

$$
\xi=\frac{\mathrm{C}}{2 \sqrt{\mathrm{KM}}}
$$

So, the amplitude of the frequency function in the viscous system is:

$$
|w|=\frac{\left|\frac{\bar{F}}{K}\right|}{\sqrt{\left(1-\Omega^{2}\right)^{2}+4 \xi^{2} \Omega^{2}}}
$$

For the equivalence of viscous and hysteresis responses, one has:

$$
\mathrm{k}_{\mathrm{dyn}}=\mathrm{k}_{\mathrm{sta}}+\mathrm{C} \mathrm{i} \omega=\mathrm{k}_{\mathrm{sta}}(1+\mathrm{i} \eta)
$$

$\mathrm{C} \omega=\mathrm{k}_{\text {sta }} \eta \therefore \mathrm{k}_{\text {sta }}=\mathrm{K}=\frac{\mathrm{E} \mathrm{A}}{\mathrm{L}}$

Likewise, the amplitude in the hysteresis system is:

$$
|\mathrm{w}|=\frac{\left|\frac{\overline{\mathrm{F}}}{\mathrm{K}}\right|}{\sqrt{\left(1-\Omega^{2}\right)^{2}+\eta^{2}}}
$$

Where, to $\Omega \simeq 1$, one has the maximum amplitude, then:

$$
|\mathrm{w}|_{\text {vis }-\max }=\left|\frac{\overline{\mathrm{F}}}{\mathrm{C} \omega}\right|=|\mathrm{w}|_{\text {his }-\max }=\left|\frac{\overline{\mathrm{F}}}{\mathrm{K} \eta}\right|
$$

To dimensionless range, also: 
$\frac{|\mathrm{w}|}{|\mathrm{w}|_{\max }}=|\overline{\mathrm{w}}|=\frac{\eta}{\sqrt{\left(1-\Omega^{2}\right)^{2}+\eta^{2}}}$

Rewriting Equation 11, one has:

$\frac{1}{|\overline{\mathrm{w}}|^{2}}=1+\frac{1}{\eta^{2}}\left(1-\Omega^{2}\right)^{2}$

Based on least squares for curve fitting method, according to Equation 12, obtained by algebra, as suggested by Gu and Sheng [16], at the points collected of the test close to the resonance frequency (n points), can make estimation of the loss factor (or damping ratio) by minimizing residual error.

$\operatorname{erro}(\eta)=\sum_{n=1}^{n}\left[y_{n}-f\left(x_{n}, \eta\right)\right]^{2}$

Expanding $f\left(x_{n}, \eta\right)$ using Taylor series around the variable $\eta=\eta_{0}$, where first order polynomial is enough, also:

$f\left(x_{n}, \eta\right) \simeq f\left(x_{n}, \eta_{0}\right)+f^{\prime}\left(x_{n}, \eta_{0}\right)\left(\eta-\eta_{0}\right)$

$\operatorname{erro}(\eta)=\sum_{n=1}^{n}\left[y_{n}-f\left(x_{n}, \eta_{0}\right)-f^{\prime}\left(x_{n}, \eta_{0}\right)\left(\eta-\eta_{0}\right)\right]^{2}$

$\mathrm{y}=\frac{1}{|\overline{\mathrm{w}}|^{2}}$

$\mathrm{f}\left(\mathrm{x}_{\mathrm{n}}, \eta\right)=\mathrm{f}\left(\Omega_{\mathrm{n}}, \eta\right)=1+\frac{1}{\eta^{2}}\left(1-\Omega_{\mathrm{n}}^{2}\right)^{2}$

The estimation of the loss factor was performed using Mathcad 2000 Professional software (MathSoft [17]), where routine was developed to adjust the theoretical curve to the experimental curve on least squares, with an initial value stipulated for the loss factor $\left(\eta_{0}\right)$.

After the first loss factor is obtained, minimizing the error, the process is repeated with this value until a second value is obtained. The iteration will be completed when the difference between the neighboring loss factors is small enough, which in this study corresponds to at least $10^{-6}$. The last iteration of the loss factor corresponds to the estimated $\eta$ value.

By analogy, within the procedure presented, it is possible to estimate the value of the damping (C), having then:

$f\left(x_{n}, C\right)=f\left(\Omega_{n}, C\right)=1+\frac{M^{2} \omega_{\text {res }}^{2}}{C^{2}}\left(1-\Omega_{n}^{2}\right)^{2}$

Thus, in this study, preference was given on least squares for curve fitting method in obtaining the loss factor and damping, considering the data of the LRF tests performed by Barreto [3], as well as to the automation achieved with the routine developed, as for the better precision of the method adopted in relation to half-power bandwidth.

This approach made possible to calculate the elasticity modulus of the tested material by the equivalence between viscous and hysteresis damping, through of the equality in Equation 7 [7] that results in Equation 8, after adjusting the 
theoretical resonance curve to the experimental curve, based on the loss factor and damping, individually, resulting in the curves showed in Figure 6.

\subsubsection{Damping in concrete mixes}

The concrete mixes used in the beams tested by longitudinal resonance, whose data were recorded in the time domain and analyzed in this study in the frequency domain, are those of the tests carried out by Barreto [3], within of the line of research on AAR developed at the Universidade Federal da Paraíba (UFPB).

Table 1 show the nomenclature of the concrete beams built for the tests of potential for reactivity of the aggregate and tested by Barreto [3] in longitudinal resonance and ultrasound, being: C \# - Cement content; I - Innocuous; R Reactive; L - Free expansion.

Table 1. Nomenclature of concrete beams (modified of Barreto [3]).

\begin{tabular}{cc}
\hline Concrete beam & Description \\
\hline $\mathrm{I} 1(\mathrm{C} 420-\mathrm{I}-\mathrm{L})$ & Dimensions $10 \times 10 \times 114 \mathrm{~cm} ;$ cement content $420 \mathrm{~kg} / \mathrm{m}^{3}$ of concrete; coarse aggregate innocuous; free expansion \\
\hline $\mathrm{I} 2(\mathrm{C} 500-\mathrm{I}-\mathrm{L})$ & Dimensions $10 \times 10 \times 114 \mathrm{~cm} ;$ cement content $500 \mathrm{~kg} / \mathrm{m}^{3}$ of concrete; coarse aggregate innocuous; free expansion \\
\hline $\mathrm{R} 1(\mathrm{C} 420-\mathrm{R}-\mathrm{L})$ & Dimensions $10 \times 10 \times 114 \mathrm{~cm} ;$ cement content $420 \mathrm{~kg} / \mathrm{m}^{3}$ of concrete; coarse aggregate reactive; free expansion \\
\hline $\mathrm{R} 2(\mathrm{C} 500-\mathrm{R}-\mathrm{L})$ & Dimensions $10 \times 10 \times 114 \mathrm{~cm} ;$ cement content $500 \mathrm{~kg} / \mathrm{m}^{3}$ of concrete; coarse aggregate reactive; free expansion \\
\hline
\end{tabular}

Note: Nomenclature in parentheses "()" corresponds the adopted in this study

Table 2 show concrete mixes affected by AAR of several authors, include Paulo Afonso IV Hydroelectric Power Plant, for comparative of elasticity modulus degradation with the mixes of Barreto [3] in LRF tests.

Table 2. Concrete mixes affected by AAR of several authors for comparative of elasticity modulus degradation (AUTHOR).

\begin{tabular}{|c|c|c|c|c|c|c|c|c|}
\hline \multirow{2}{*}{ Author } & \multirow{2}{*}{ Mix } & \multirow{2}{*}{ Reactive Aggregate } & \multirow{2}{*}{ Cem. } & \multirow{2}{*}{$\mathbf{w} / \mathbf{c}$} & \multirow{2}{*}{$\frac{\mathbf{E}}{\mathrm{GPa}}$} & \multirow{2}{*}{$\begin{array}{c}\mathbf{T} \\
{ }^{\circ} \mathbf{C}\end{array}$} & \multirow{2}{*}{$\frac{\mathrm{h}}{\%}$} & \multirow{2}{*}{$\frac{\mathrm{Na}_{2} \mathrm{O}_{\mathrm{eq}}}{\%}$} \\
\hline & & & & & & & & \\
\hline \multirow{2}{*}{ Barreto [3] } & C420-R-L & \multirow{2}{*}{ Quartz, biotite, Albite and microline (coarse) } & 420 & 0.45 & 25.90 & $36-40$ & $>95$ & 1.47 \\
\hline & C500-R-L & & 500 & 0.45 & 29.58 & $36-40$ & $>95$ & 1.47 \\
\hline Larive [10], [11] & - & Tournaisis limestone (thin and coarse) & 410 & 0.44 & - & 38 & 97 & 1.25 \\
\hline ISE [10] & & $1 *$ & & & & & & \\
\hline PA-IV [10] & - & Biotite-gneiss, rosy granite and amphibolite (coarse) & 357 & 0.53 & 25.00 & 38 & 100 & 0.92 \\
\hline \multirow{2}{*}{ Esposito [11] } & RR1 & Quartzite, quartz, limestone, volcanic rock fragments (fine and coarse) & 380 & 0.46 & 42.70 & 38 & 96 & 1.17 \\
\hline & RR2 & Coarse-grained quartz, quartzite, gneiss, metariolite (fine and coarse) & 380 & 0.45 & 30.46 & 38 & 96 & 1.17 \\
\hline \multirow[b]{2}{*}{ Giaccio et al. [12] } & $\mathrm{R} 2$ & Opal and chalcedony (thin) & 420 & 0.42 & 32.00 & 38 & \multirow[b]{2}{*}{ * } & 1.25 \\
\hline & R4 & $\begin{array}{c}\text { Feldspars (orthoclase and plagioclase), quartz, mica, epidote, zircon and } \\
\text { dark minerals (coarse) }\end{array}$ & 420 & 0.42 & 38.10 & 38 & & 1.25 \\
\hline Swamy [13] & $4.5 \%$ opal & Beltane Opal (thin) & 520 & 0.44 & - & 20 & 96 & 1.00 \\
\hline Sanchez et al. [14] & $\mathrm{Wt}+\mathrm{HP} 35$ & Polymeric sand, quartz and feldspar (fine) & 370 & 0.47 & - & 38 & 100 & 1.25 \\
\hline Ahmed et al. [15] & $\mathrm{B}$ & Fused Silica (fine) & 400 & 0.50 & 21.13 & 38 & $3 *$ & 1.75 \\
\hline
\end{tabular}

Note: $1 *$ - Lab and test data on cores extracted of structures; $2 *$ - Plastic bag with $5 \mathrm{ml}$ of water; $3 *$ - In the water; E - Elasticity (28 days); T - temperature;

h - humidity; $\mathrm{Na}_{2} \mathrm{O}_{\text {eq }}$ - Alkaline Equivalent; ISE - Institution of Structural Engineers; PA-IV - Paulo Afonso IV Hydroelectric Power Plant

\subsubsection{Resonance simulation in concrete specimens}

Considering the LRF tests used in this study, combined with the mathematical and mechanical analysis that considered the equivalence between viscous and hysteresis damping, was used routine developed in Mathcad 2000 to obtain parameters of damping.

Longitudinal resonance simulations in finite elements of bars (1D) are also performed using Mathcad 2000, where the algorithmic damping Newmark method provided the results to be transformed of the time domain to the frequency domain, where the frequency spectra of the tests and simulations are consistent with the reality of the tested concrete, as well as in the steel used in test procedure.

Figure 9 show FRF obtained of experimental test and other possible FRFs resulting of finite elements simulation using algorithmic damping Newmark method, where displacement, velocity and acceleration are considered originated of simulated longitudinal excitation, in the same mold of the tests, for the same concrete in the same test period.

Differences exist due difficulties of approximation modeling in complex material such as concrete affected by AAR, but the results are fully compatible. 
Like in Figure 6, in Figure 9 there are two "peaks" arising of other accessory modes in the test (2nd and 3rd experimental mode). In this sense, the simulation plays an important role, which corresponds previously to identify the correct "peak" of longitudinal resonance for the analysis of the viscoelastic parameters, through of adjustment of the dimensionless theoretical curve using least squares.

For the case in Figure 9, considering geometry and properties of the analyzed concrete, the longitudinal resonance in LRF test corresponded to the largest "peak" in the expected extension of the spectrum, i.e., the 1st mode.

However, it's worth noting that due to the appearance of accessory modes (transverse, flexural and torsional vibration) this situation may not always occur, emphasizing the importance of prior identification of the longitudinal resonance modes through of simulation as well as existence of behavioral adherence between experimental and theoretical resonance.

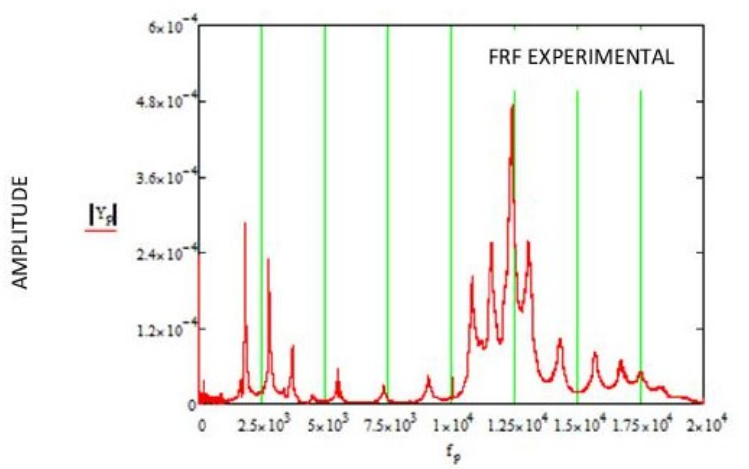

FREQUENCY $(\mathrm{Hz})$
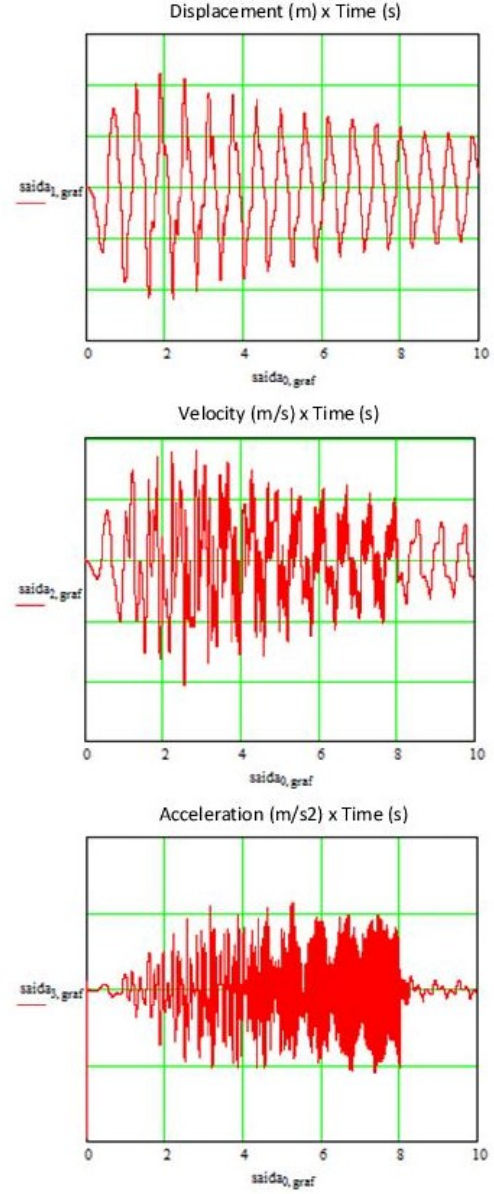
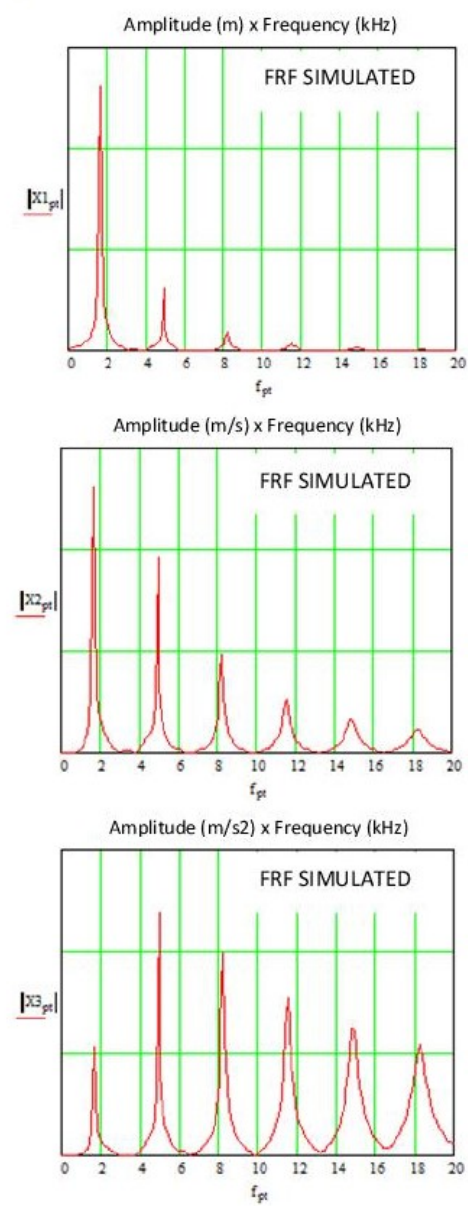

Figure 9. FRFs experimental and simulated (concrete C420-R-L for 1 day); 1st and 2nd simulated modes $\simeq 1.6$ and $4.9 \mathrm{kHz}$; corresponding to the simulated: 1 st and 4 th experimental modes $\simeq 1.8$ and $5.4 \mathrm{kHz}$ (AUTHOR). 


\subsubsection{Concrete rheology}

To exemplify changes in the viscoelastic behavior of the material, it's common to use rheological models (mechanical analogies), as spring to explain the instantaneous elasticity and damper to characterize the viscous behavior, that is, the late response of the material in time.

Tests and observations made as function of the time configure the material behavior in long-term and take time to complete. One possibility of reducing time is to subject the material the load in which stress or strain varies harmonically in short period of time, that is, analysis as function of the frequency. This makes it possible to identify the viscoelastic characteristics of the material more quickly.

Thus, whether in the time or frequency, the rheological behavior of materials can be represented using viscoelastic models, which combine behaviors of elastic solids and viscous fluids [18].

- Rheology in time

Figure 10 show the main families of rheological models, where their creep functions over time are described in Table 3.

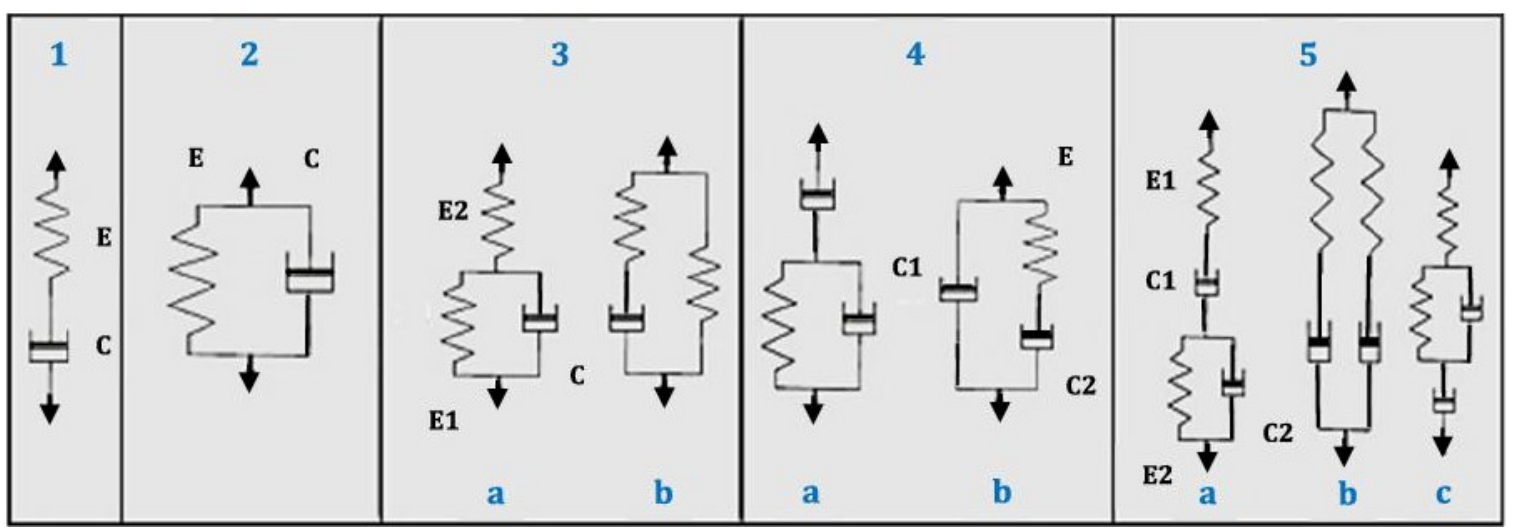

Figure 10. Rheological models: 1) Maxwell; 2) Kelvin-Voigt; 3) Zener; 4) antiZener; 5) Burgers (AUTHOR).

Table 3. Creep functions of the models (unitary) (AUTHOR).

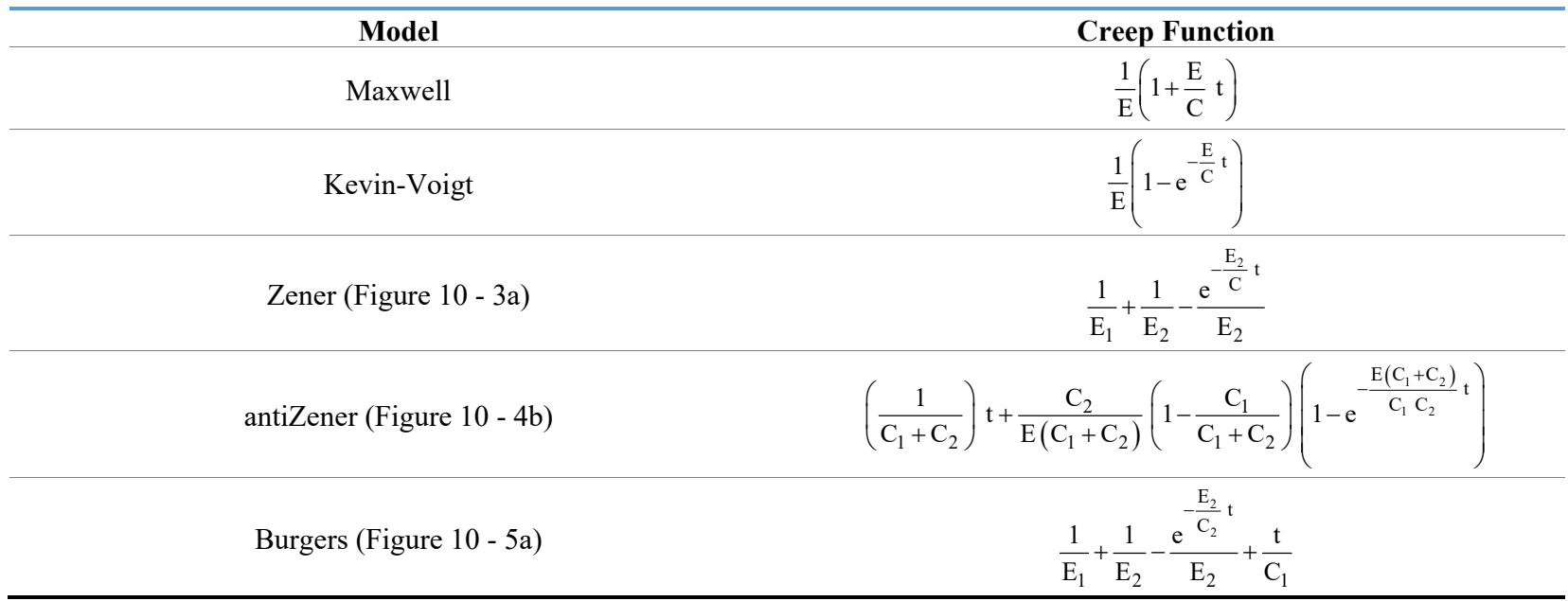

\section{- Rheology in frequency}

Table 4 [19], [20] show summary of the complex modulus functions, complemented in this study by the Burgers model, as function of the frequency. 
Table 4. Complex modulus of the rheology considered (Renaud et al. [19]; Semblat and Luong [20]).

\begin{tabular}{cc}
\hline Model & Complex Modulus \\
\hline Histerese & $\frac{\mathrm{E}(1+\mathrm{i} \eta)}{\mathrm{i} \omega \mathrm{E} \mathrm{C}}$ \\
\hline Maxwell & $\mathrm{E}+\mathrm{i} \omega \mathrm{C}$ \\
\hline Kelvin-Voigt & $\frac{\mathrm{E}_{1}\left(\mathrm{E}_{2}+\mathrm{i} \omega \mathrm{C}\right)}{\mathrm{E}_{1}+\mathrm{E}_{2}+\mathrm{i} \omega \mathrm{C}}$ \\
\hline Zener (Figure $10-3 \mathrm{a})$ & $\frac{{\mathrm{E} \mathrm{i} \omega \mathrm{C}_{2}}_{\mathrm{i} \omega \mathrm{C}_{2}+\mathrm{E}}+\mathrm{i} \omega \mathrm{C}_{1}}{\left(\frac{1}{\mathrm{E}_{1}}+\frac{1}{\mathrm{i} \omega \mathrm{C}_{1}}+\frac{\mathrm{E}_{2}+\mathrm{i} \omega \mathrm{C}_{2}}{1}\right)^{-1}}$ \\
\hline antiZener (Figure $10-4 \mathrm{~b})$ & $($ Figure $10-5 \mathrm{a})$ \\
\hline
\end{tabular}

* AUTHOR

Thus, the ideia in this study is to consider models for representative rheologies of viscoelastic solids, such as Zener and Burgers, that will be evaluated as to its applicability for structural engineering in damage models.

\subsubsection{Quality factor}

The families of rheological models considered as function of the frequency can be defined in terms of the quality factor ( Q ), which corresponds to one almost constant variable in the frequency range in given level of deformation introduced.

Attenuation curves are constructed taking the inverse of the quality factor $\left(\mathrm{Q}^{-1}\right)$, where:

$$
\mathrm{Q}(\omega)=\frac{\operatorname{Re}[\mathrm{E}(\omega)]}{\operatorname{Im}[\mathrm{E}(\omega)]}
$$

Since $\operatorname{Re}[\mathrm{E}(\omega)]$ is the real part of the complex modulus and $\operatorname{Im}[\mathrm{E}(\omega)]$ is its imaginary part, to $\omega=\omega_{\text {res }}$ in the 1 st and 2 nd modes also:

$\mathrm{Q}^{-1}=\eta=2 \xi$

\subsubsection{Damping and rheology}

Considering numerical modeling purposes, another type of damping is often used: Rayleigh damping; which is one very convenient way to account damping in numerical models and to associate them with rheological models, as intended in this study.

Rayleigh damping is a classic method to build the global damping matrix [C] of a number system as linear combination of global matrices of mass $[\mathrm{M}]$ and stiffness $[\mathrm{K}]$, as follows:

$[\mathrm{C}]=\alpha[\mathrm{M}]+\beta[\mathrm{K}]$

Equation 21 makes frequency-dependent damping, as shown in Figure 11 [21].

In the condition of resonance $(\omega=\sqrt{\mathrm{K} / \mathrm{M}})$ also:

$\mathrm{C}=\xi \mathrm{C}_{\mathrm{c}}=\xi 2 \mathrm{M} \omega$

$\alpha \mathrm{M}+\beta \mathrm{K}=\xi 2 \mathrm{M} \omega$

$\xi=\frac{1}{2}\left(\frac{\alpha}{\omega}+\beta \omega\right)$ 
Thus, considering Equation 24, one has:

$\mathrm{Q}^{-1}(\omega)=\frac{\alpha}{\omega}+\beta \omega$

Where $\alpha$ and $\beta$, considering the damping ratio $\xi$ in the extension of the circular frequency of interest, between the 1st and 2nd vibration modes, $\omega_{1}$ and $\omega_{2}$, respectively, as shown in Figure 11, correspond to:

$\alpha=\frac{2 \omega_{1} \omega_{2}\left(\xi_{1} \omega_{2}-\xi_{2} \omega_{1}\right)}{\left(\omega_{2}^{2}-\omega_{1}^{2}\right)}$

$\beta=\frac{2\left(\xi_{2} \omega_{2}-\xi_{1} \omega_{1}\right)}{\left(\omega_{2}^{2}-\omega_{1}^{2}\right)}$

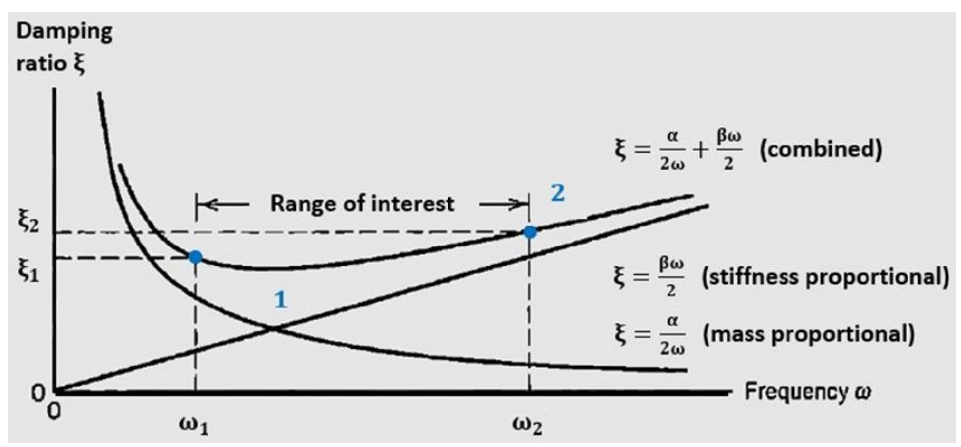

Figure 11. Proportional Damping Scheme [21].

Crucial point is to discover a rheological model that has the same attenuation dependence as those showed in Figure 11, which are based on Rayleigh damping [22].

As reference, in riveted or welded steel structures and reinforced and prestressed concrete structures the value of $\xi$ can vary of $2-15 \%$ [23]. In particular, Gutenbrunner et al. [4] presents values of $\xi$ for prestressed concrete bridge ranging of $1.19-1.37 \%$.

This study, the connection of the numerical parameters of the Rayleigh damping ( $\alpha$ and $\beta$ ) to the mechanical parameters described in Figure 10 are shown in Table 5.

Table 5. Relationship between numerical parameters of the Rayleigh damping and mechanical (AUTHOR).

\begin{tabular}{ccc}
\hline Model & $\boldsymbol{\alpha}$ & $\boldsymbol{\beta}$ \\
\hline Histerese & $\frac{\mathrm{E}}{\mathrm{C}}$ & - \\
\hline Maxwell & - & $\frac{\mathrm{C}}{\mathrm{E}}$ \\
\hline Kelvin-Voigt & $\frac{\mathrm{E}_{2}+\frac{\mathrm{E}_{2}^{2}}{\mathrm{E}_{1}}}{\mathrm{C}}$ & $\frac{\mathrm{C}}{\mathrm{E}_{1}}$ \\
\hline Zener (Figure 10 - 3a) & $\frac{\mathrm{E}\left(\mathrm{C}_{1}+\mathrm{C}_{2}\right)}{\mathrm{C}_{2}^{2}}$ & $\frac{\mathrm{C}_{1}}{\mathrm{E}}$ \\
\hline antiZener* (Figure 10 - 4b) & By analogy: $\mathrm{E}_{1}=\mathrm{E}_{\text {maxwell }} ; \mathrm{E}_{2}=\mathrm{E}_{2}$ (zener) $; \mathrm{C}_{1}=\mathrm{C}_{2}$ (antizener) $\mathrm{C}_{2}=\mathrm{C}_{\text {kelvinvoigt }}$
\end{tabular}

\footnotetext{
* Semblat [22]
} 


\subsection{Part 2: numerical validation of experimental data}

Figure 12 show the evolution of FRFs and theoretical curves to loss factor $(\eta)$ of the concrete C420-R-L, in five different ages, with the first three corresponding to the initial ages of the concrete (1-14-29 days), one close to half the test time (379 days) and the last in the end of the test (514 days), where it's possible to notice noise in some cases, but which did not affect the curve adjustment on least squares in the obtaining of the global viscoelastic parameters of the concrete, among them the elasticity modulus.

FRFs longitudinal experimental and theoretical dimensionless resonance curves adjusted by the loss factor $(\eta)$ and damping (C), resulting of the data collected in the resonance tests and analyzed in this study, made it possible to obtain the values in Table 6.

It can be seen from Table 6 that the increase in the loss factor is accompanied through the decrease in the elasticity modulus of the concrete C420-R-L.

In sequence, Figure 13 show the elasticity modulus degradation in free expansion of the concretes C420/500-R-L, compared to several authors, likewise that Kawabata et al. [24].
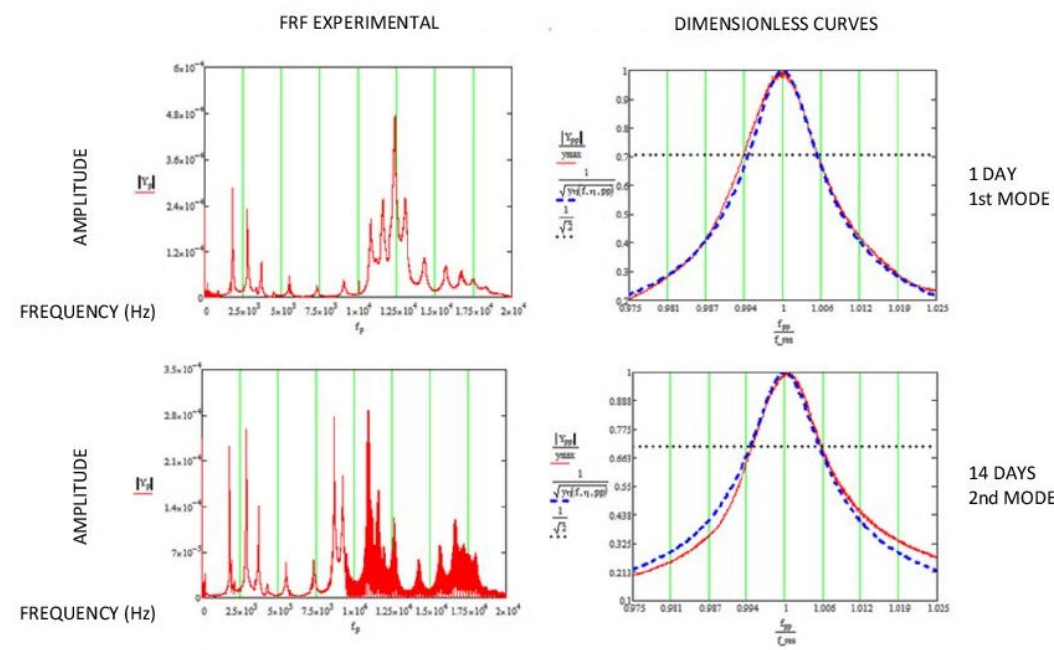

2nd MODE
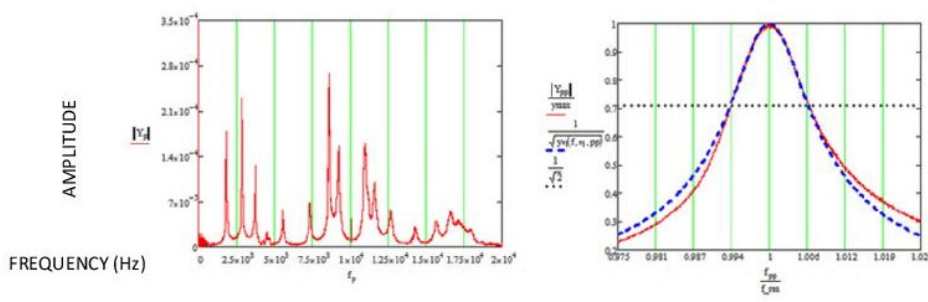

29 DAYS
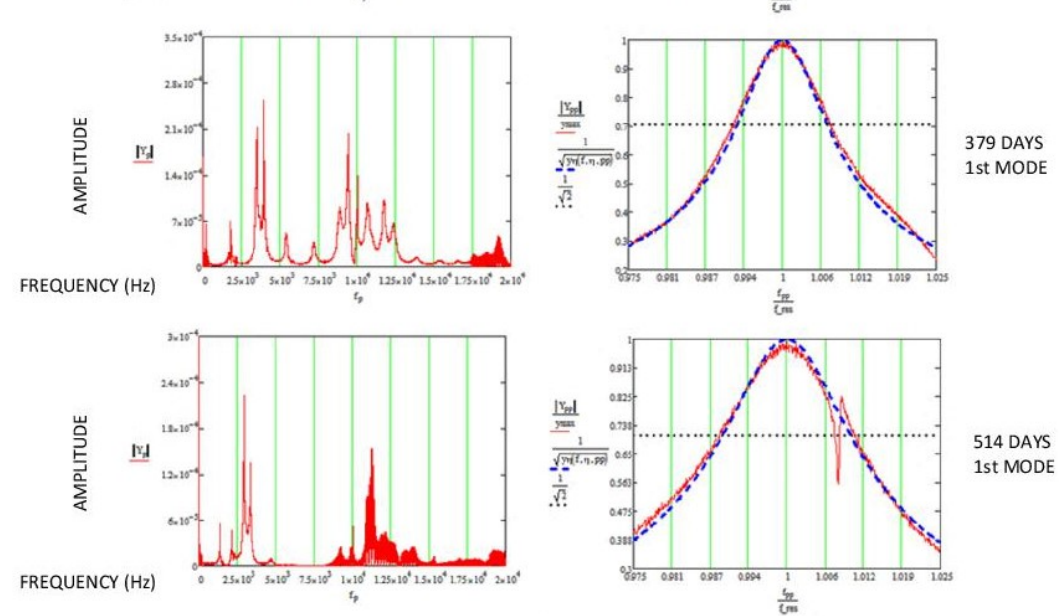

Figure 12. FRFs and curves for $\eta$ (experimental - continuous line; theoretical - dashed line) (AUTHOR). 
Table 6. Global parameters obtained by longitudinal resonance analysis: concrete C420-R-L (see Figure 12) (AUTHOR).

\begin{tabular}{ccccccc}
\hline Time (days) & Expansion (\%) & Amplitude & $\boldsymbol{\omega}_{\text {res }}(\mathbf{H z})$ & $\boldsymbol{\eta}$ & $\mathbf{C}(\mathbf{P a} \cdot \mathbf{s})$ & $\mathbf{E}(\mathbf{G P a})$ \\
\hline 1 & 0 & 0.000285455 & $1,829.9$ & 0.01118 & 580.78264 & 10.84121 \\
\hline 14 & 0.008 & 0.000257711 & 2,871 & 0.01141 & 930.25535 & 26.68638 \\
\hline 29 & 0.02 & 0.000230823 & $2,828.4$ & 0.01302 & $1,046.09$ & 25.90031 \\
\hline 379 & 0.094 & $7.01 \mathrm{E}-05$ & $1,781.7$ & 0.01467 & 742.27642 & 10.27766 \\
\hline 514 & 0.104 & $5.48 \mathrm{E}-05$ & $1,350.9$ & 0.02087 & 800.86654 & 5.90843 \\
\hline
\end{tabular}

\section{Elasticity Modulus Degradation (E/Eo) x Expansion (\%)}
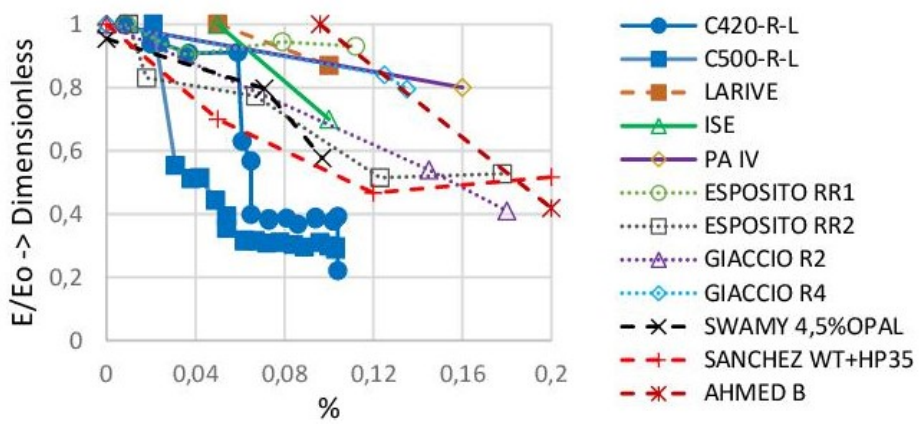

Figure 13. Elasticity modulus degradation of the concretes C420/500-R-L compared to several authors (see Table 2) (AUTHOR).

Figure 14, that considers temporal analysis of rheological models to creep and relaxation, show the prediction behavior of the Zener and Burgers models, as models capable of to predict the behavior of the concretes affected by the AAR, in creep, tested in free expansion.

Figure 15 show that the models that respond well in the frequency range applied to LRF tests, between $100 \mathrm{~Hz}$ and $20 \mathrm{kHz}$, are: hysteresis, Maxwell, Kelvin-Voigt and antiZener. This behavior serves to consolidate the equivalence used to the hysteresis and Kelvin-Voigt (viscous) models in the damping. Still, considering frequency analysis through of attenuation curves for loss factor have Zener, antiZener and Burgers models that take similar shape to the combined damping in Figure 11.
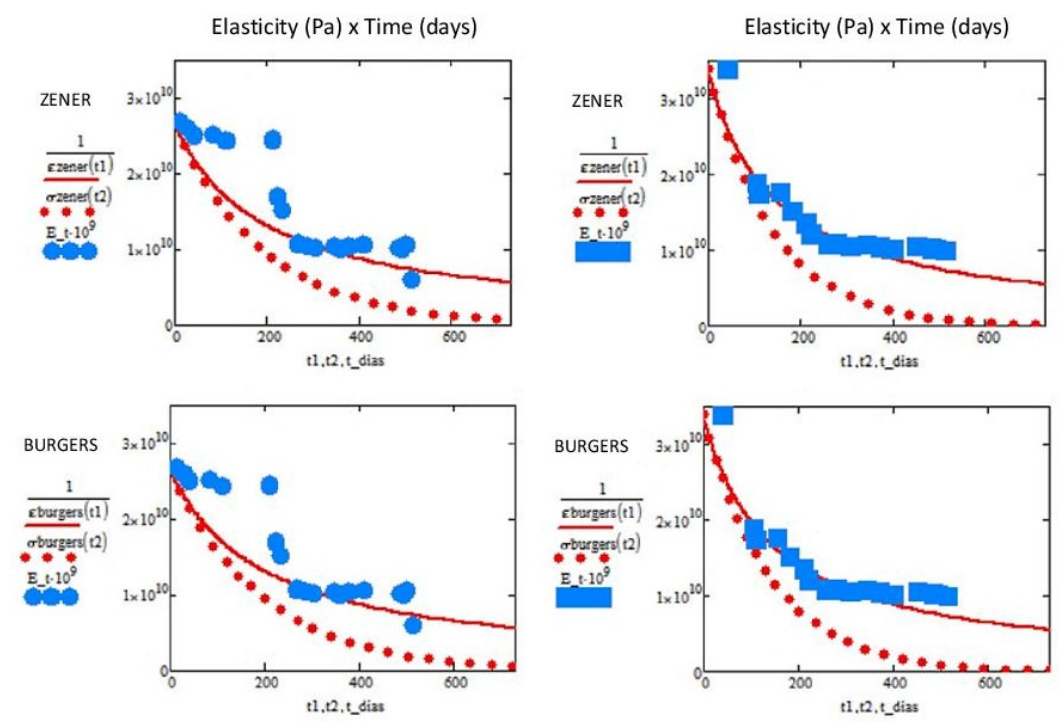

C420-R-L

C500-R-L

Figure 14. Elasticity modulus of the concretes C420/500-R-L; creep - continuous line; relaxation - dotted line; experimental - dot (AUTHOR). 
Complex Modulus $(\mathrm{Pa}) \times$ Frequency $(\mathrm{Hz})$

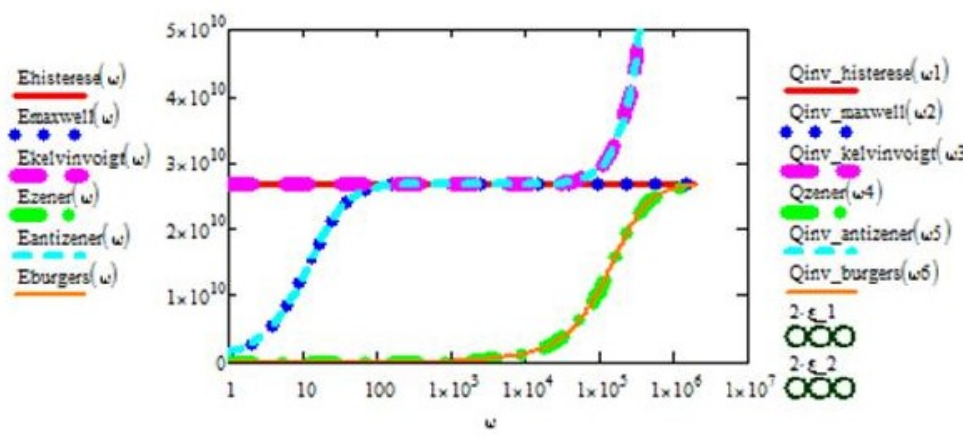

Loss Factor $x$ Frequency $(\mathrm{Hz})$

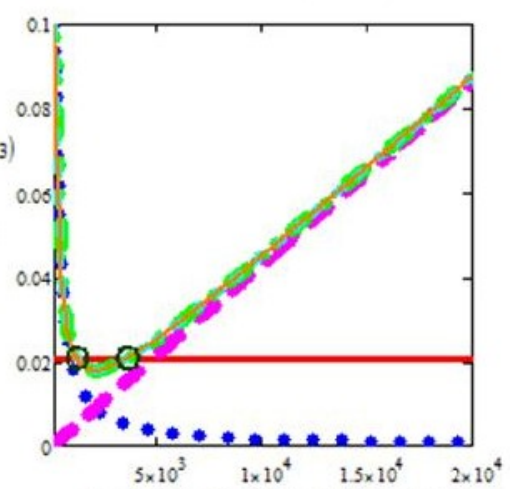

$\omega 1, \omega 2, \omega 3, \omega 4, \omega 5, \omega 6, f_{-} h v_{0}-1000, f_{-} h z_{-}-1000$

Figure 15. Complex modulus and attenuation curve (loss factor): concrete C420-R-L (AUTHOR).

\section{CONCLUSIONS}

- The use of modal analysis in the frequency spectrum in longitudinal resonance makes it possible to determine nondestructively the global rheological properties of concrete samples, such as: damping, loss factor and elasticity modulus;

- Using finite elements technique to simulate longitudinal resonance tests, including algorithmic damping Newmark method to obtain response patterns in the frequency, coupled with deconvolution made possible by the Rayleigh approach, mechanical parameters of the rheological models are quantified using numerical parameters of Rayleigh damping;

- Considering frequency extension, Kelvin-Voigt (viscous) and hysteresis models obtained similar response in the analyzes between approximately $100 \mathrm{~Hz}$ and $60 \mathrm{kHz}$, validating the equivalence adopted in this study between viscous and hysteresis damping;

- In dependence of attenuation the Zener, antiZener and Burgers models showed similar response to the combined Rayleigh damping of mass and stiffness, being antiZener (Standard Linear Liquid) modeling, for viscous fluid, atypical matter in structural engineering;

- In models whose behavior combines damping with mass and stiffness in the frequency, the validation of experimental results with behavior predicted in models representative of rheology that considers viscoelastic solids of the type Zener and Burgers complements and expands the interest of the structural engineering for those models in damage.

\section{ACKNOWLEDGMENTS}

This work was funded by the Companhia Hidro Elétrica do São Francisco (Chesf) as part of P\&D project and had the technical support of the Universidade Federal da Paraíba (UFPB), especially of Barreto [3] for the tests performed.

\section{REFERENCES}

[1] J. Butterworth, J. H. Lee, and B. Davidson, "Experimental determination of modal damping from full scale testing," in Proc. 13th World Conf. Earthq. Eng. (310), Vancouver, Canada, Aug. 2004

[2] K. J. Leśnicki, J.-Y. Kim, K. E. Kurtis, and L. J. Jacobs, "Characterization of asr damage in concrete using nonlinear impact resonance acoustic spectroscopy technique," NDT Int., vol. 44, pp. 721-727, 2011.

[3] A. M. Barreto, “Técnicas não destrutivas para detecção da reação álcali-agregado em prismas de concreto,” Ph.D. dissertation, Univ. Fed. Paraíba, João Pessoa, 2019.

[4] G. Gutenbrunner, K. Savov, and H. Wenzel, "Sensitivity studies on damping estimation," in 2nd Int. Conf. Exp. Vib. Anal. Civ. Eng. Struct., Porto, Portugal, 2007.

[5] Associação Brasileira de Normas Técnicas, Concreto Endurecido - Determinação da Velocidade de Propagação de Onda Ultrassônica, ABNT NBR 8802, 2019.

[6] A. Nagy, "Cracking in reinforced concrete structures due to imposed deformations," Ph.D. dissertation, Lund Univ., Lund, Sweden, 1997. 
[7] A. D. Nashif, D. I. G. Jones, and J. P. Henderson, "Modeling of structural response of damped systems," in Braun-Brumfield Inc., Ed., Vibration Damping, New York, USA: Jonh Wiley \& Sons Inc., 1985, Chap. 4.

[8] Agilent Technologies, Agilent 33220A 20 MHz Waveform Generator User's Guide. USA: Agilent Technologies Inc., 2007.

[9] American Society for Testing and Materials, Standard Test Method for Measuring Vibration-Damping Properties of Materials, ASTM E 756, 1998.

[10] COPEM, “Relatório de Modelagem e Recalibração das Estruturas da Usina de PA-IV, CH01-C-0031-R6, 2001.

[11] R. Esposito, "The deteriorating impact of alkali-silica reaction on concrete - expansion and mechanical properties", Ph.D. dissertation, Univ. Parma, Parma, Italy, 2016.

[12] G. Giaccio, R. Zerbino, J. M. Ponce, and O. R. Batic, "Mechanical behavior of concretes damaged by alkali-silica reaction," Cement Concr. Res., vol. 38, pp. 993-1004, 2008.

[13] R. N. Swamy, "Assessment and rehabilitation of aar-affected structures," Cement Concr. Compos., vol. 19, pp. 427-440, 1997.

[14] L. F. M. Sanchez, B. Fournier, M. Jolin, D. Mitchell, and J. Bastien, "Overall assessment of Alkali-Aggregate Reaction (AAR) in concretes presenting different strengths and incorporating a wide range of reactive aggregate types and natures," Cement Concr. Res., vol. 93, pp. 17-31, 2017.

[15] T. Ahmed, E. Burley, S. Rigden, and A. Abu-Tair, "The effect of alkali reactivity on the mechanical properties of concrete," Constr. Build. Mater., vol. 17, pp. 123-144, 2003.

[16] J. Gu and M. Sheng, "A method for damping estimation based on least square fit," Am. J. Eng. Res., vol. 4, no. 7, pp. $205-209,2015$.

[17] MathSoft, Mathcad 2000 User's Guide. USA: MathSoft Inc., 2000.

[18] R. F. Navarro, "Modelos viscoelásticos aplicáveis a materiais reais: uma revisão," Rev. Eletronica Mater. Processos, vol. 12, no. 1, pp. 1-20, 2017.

[19] F. Renaud, J.-L. Dion, G. Chevallier, I. Tawfiq, and R. Lemaire, "A new identification method of viscoelastic behavior: application to the generalized maxwell model," Mech. Syst. Signal Process., vol. 25, pp. 991-1010, 2011.

[20] J. F. Semblat and M. P. Luong, "Wave propagation through soils in centrifuge testing," J. Earthquake Eng., vol. 2, no. 1, pp. 147$171,1998$.

[21] R. D. Cook, D. S. Malkus, M. E. Plesha, and R. J. Witt, "Finite elements in structural dynamics and vibrations," in Concepts and Applications of Finite Element Analysis, Hamilton Printing Company, Ed., 4th ed., Madison, USA: John Willey \& Sons, 2002, Chap. 11.

[22] J. F. Semblat, "Rheological interpretation of rayleigh damping," J. Sound Vibrat., vol. 206, no. 5, pp. 741-744, 1997.

[23] L. E. Vaz, "Análise dinâmica de estruturas," in Método dos Elementos Finitos em Análise de Estruturas, Globaltec Editora Ltda., Ed., Rio de Janeiro: Elsevier Editora Ltda./Campus, 2011, Cap. 9.

[24] Y. Kawabata, J. F. Seignol, R. P. Martin, and F. Toutlemonde, "Influence of creep and stress states on alkali-silica reaction inducedexpansion of concrete under restraint," in Proc. 15th Int. Conf. Alkali-Aggregate Reaction in Concr. (32), São Paulo, July, 2016.

Author contributions: M. B. Cavalcanti: conceptualization, formal analysis, writing; S. M. Torres: funding acquisition, supervision, data curation; M. R. F. L. Filho: methodology; and A. J. V. Santos: methodology.

Editors: Edna Possan, José Luiz Antunes de Oliveira e Sousa, Guilherme Aris Parsekian. 